\title{
Utilization of Natural Resources in the Mining Sector Related to the State Welfare
}

\author{
Hamdan Azhar Siregar \\ Faculty of Law \\ Jakarta Islamic University \\ Jakarta, Indonesia \\ Hamdan_sir@y ahoo.co.id
}

\author{
Untoro \\ Faculty of Law \\ Jakarta Islamic University \\ Jakarta, Indonesia \\ untoro_uid@yahoo.co.id
}

\author{
Teuku Saiful Bahri \\ Faculty of Law \\ Jakarta Islamic University \\ Jakarta, Indonesia \\ mrhasan95@yahoo.com
}

\begin{abstract}
Indonesia has a huge of natural resources such as mining, plantation, forestry, marine, these natural resources should be able to change the life of society as a whole. The state has not been able to utilize its natural wealth maximally. It can be seen that the sectors mentioned above have not been managed independently by the Indonesian Nation. To achieve this proficiency, it is necessary to be independent in the management of natural resources, so that the results and its significances can be used for welfare for the people of Indonesia. This research used normative juridical research, with descriptive nature of analysis, while data collection technique were done through library study or document study, but field data was also used to support and complete library data. After the data were collected, then they were analyzed by juridical qualitative method. The utilization of the natural resources of the mining sector has not been in accordance with the provisions and the meaning of the Five Principles of Social Justice Pancasila. Social justice for all Indonesians means that every Indonesian person gets fair treatment, both in law, economics, politics, culture and social, based on Pancasila and UUD45. As adherents to the concept of the welfare state (Welfare S tate), this concept has a goal to achieve prosperity for society. The state as the subject of law has a serious obligation to realize prosperity and welfare for its citizens. In the fifth principle of Pancasila namely social justice for all Indonesian people. One form of government intervention is the responsibility in the field of economy, in order to achieve and create the prosperity of the $S$ tate, it must be regulated in law to avoid arbitrary action or exceed the limit power equipment, known as the "rule of law".
\end{abstract}

\section{Keywords-Natural Wealth, Mining, People's Welfare}

\section{INTRODUCTION}

Indonesia is a rich country in natural resources, such as petroleum, gold, coal, silver, and copper and so on. Natural wealth is scattered in various regions, from Sabang to Merauke. This natural wealth becomes something to be proud of and a source of livelihood and income of the state. However, the resources of the natural cannot last eternally, they will gradually be exhausted and irreplaceable.

If seen from its control, Indonesia is a country that is not yet able to utilize its natural wealth maximally. It can be seen that there are still many mining sectors that cannot be managed independently. In other words the mastery of mining is submitted to private or foreign companies. Inability to independently manage natural resources is due to several factors such as human resources, capital, and technology.
In accordance with the Constitution of the Republic of Indonesia, Article 33 Paragraph (3) of the 1945 Constitution states that: "the earth, the water, and the natural resources contained therein are controlled by the state and used for the greatest prosperity of the people". So the earth and the water and the natural wealth contained therein are the principal prosperity of the people[1]. Therefore it must be controlled by the government and should not be controlled by individuals or other business [2]. W ith the control from the State, the natural resources possessed by the Indonesian nation are fitting for the benefit of all the people of Indonesia.

\section{A. Problem Formulation}

Based on the above background, the problem formulations in this paper are:

1. What causes mining beneficiaries cannot be controlled by the Indonesian government?

2. How can the concept of the State in mining sector provide prosperity for the people of Indonesia?

\section{B. Theoretical Framework}

The concept of the Welfare State aims to bring prosperity to society, the state as the subject of the law has a serious obligation to realize prosperity and welfare for its citizens. In the fifth principle of Pancasila that is social justice for all Indonesian people, one form of government intervention is the responsibility in the economic field. To achieve and create the prosperity of the State, it must be regulated in law to avoid the arbitrary action or exceed the limits of the power of the instrument its equipment, known as the "rule of law"[3][4]. ${ }^{1}$

A Welfare State is a system that gives a big role to Social (Government) to provide and implement Social Security welfare through development in a planned and sustainable to the community as a whole[5]. It was these developments that gave legalization to the "interventionist" state that began in the 20thcentury. The state precisely and even had to

\footnotetext{
${ }^{1}$ Furthermore Rule Of Law according to the Five Year Development Plan I See SoetandyoWignyosoebroto explains From Colonial Law to the National Law of Political Social Dynamics in National Law Development, Rule Of Law page. 228., it includes the following three elements of the policy: first of all that human rights are recognized and protected; secondly, that the judiciary should be free and impartial, and that the principle of legality would be firmly upheld, whether in the application of formal law or in the application of the matrix law
} 
intervene in various social and economic is sues to ensure the creation of common prosperity in society[6]. Thus, the responsibility to promote the general welfare - as aspired in the opening of the Indonesian Constitution as the objective of the establishment of an independent Indonesian state-isa joint responsibility between the government and the community as a family[7].

A state is said to be prosperous if it has four main pillars, among others: 1) Socialization of rights and obligations of the country (Social Citizenship) (2) Full Democracy (3) Modern Industrial Relation Systems (4) Right to educations as the expansionof modern mass education system[8].

Furthermore, Richard Quinny[9] mentioned, the main purposes of the state welfare are as follows:

1. Control and utilize socio-economic resources for social purposes;

2. Ensure the distribution of natural resources fairly and equitably;

3. Reduce poverty;

4. Provide social insurance (education and health) for the poor;

5. Provide subsidies for basic social services for the community;

6. Give social protection to every citizen.

This fact also encourages the emergence of a new awareness of the importance of state involvement in addressing and overcoming the problems of inequality that exist in society. The state cannot keep quiet for improving the welfare of society. The state needs to intervene in arranging for the resources of prosperity to be not controlled by a handful of people. The government prioritizes the interests of all people (prosperity) based on justice, but is still limited by the Law so as not to act arbitrarily and finally placing Indonesia as a welfare state can be realized [10]. ${ }^{2}$

\section{DISCUSSION}

\section{A. The causes of mining users cannot be controlled by the} Indonesian government.

The state's unprofessional tenure of mining in Indonesia has had an impact on the contribution to income and welfare of the people. Besides, the regulation that has not been able to provide direction and independence in the scaling of natural resources, possibly because the government has not been able to independently manage the mine sector. In order to achieve this goal, the need for independence and the absence of private and foreign companies in the management of natural resources owned by the Indonesian nation is needed. Independence is very important in order to use the results and its significances can be used to improve the welfare of the people of Indonesia.

Based on the wealth of natural resources owned by Indonesia, the Indonesian people should live on their own welfare. Therefore the Indonesian nation must stand on their own feet. Indonesia needs capital and technology. However, to achieve that means, it must make arrangement of the

\footnotetext{
2 Explain the comparison of monarchical and absolute countries, born a modern legal state better known as the welfare state that prioritizes the interests of all people (Walfare state). In this type of Third state states assume greater responsibility. The government of a modern state in charge besides maintaining the security of its people also serves to promote the welfare of its people.
}

existing regulations. Structuring is important for the sake of Indonesia's natural resources can be enjoyed by the entire people of Indonesia. Many legislations governing mining, however, has not been maximally seen as an attempt to favor the interests of the Indonesian people. Many of the mining sectors are still controlled by private and foreign sectors, for example the unfinished Freeport in the takeover by the Indonesian government. In 2018 there was news that Indonesia has controlled $51 \%$ of Freeport shares through PT. Inalum. But the certainty of ownership has not got the final legal certainty.

\section{B. The concept of the State through mining can provide prosperity for the people of Indonesia.}

In Article 33, Paragraph 1 of the economic arrangement it is based on togetherness, Paragraph 2 asserts that the people have the right to participate in production and to enjoy the results in order to improve the welfare. While Article 33 Paragraph 3 clearly states that the state must control the various natural resources that exist and the people have full rights to the wealth. In Article 34, the constitution affirms the right of the poor and neglected children to obtain the basic needs fulfilled by the state. If the two articles are interpreted together, then the existence of Article 33 which regulates the state must control the natural resources and not granted his control to the private and foreign companies because the state task is in accordance with the constitutional mandate.

However, since natural resources are not interpreted as wealth or government capital, there has been a paradigm shift that places mining such as: coal, crude oil, gas and other mines merely commodities can be controlled and traded freely by private and foreign company. As a result of that assumption, the impacts that result in mining being easily exploited and exported with the calculation of overseas sales are considered to be profitable.

In this context, welfare and prosperity are in accordance with the concept of the welfare state. The concept of the welfare state is the role of the state interferes not only in the economic field but it has also transcended in all aspects of people's lives. This is a form of state responsibility to its people as responsible in the life of the state.

In the case of the welfare country, Indonesia is no exception as it has been regulated in the 1945 Constitution, the welfare state is an idea that emerged after a relatively long span of time, Capitalistic practice provides many access to the disadvantage of some people, and only benefit some others. The correction given to capitalis $m$ is that it is not as ideal as predicted in the thought of the well-being. It will be created by itself with the kind of composition. In reality, many records can be given to the practice of capitalism government.

The first, country that gave the competition to run freely has given rise to the rich get richer, while the poor become poorer. That is because, the more accumulation of capital and wealth gathered for the rich, it will be easier to reach various facilities and will further facilitate the accumulation of further wealth. The competition in the system of capitalis $\mathrm{m}$ will become an unhealthy competition. Why so? Because people will do various attempts to win the competition, tricks and something that is considered not fair enough will be taken as well. 
Secondly, without the intervention of the government, competition in capitalism will become unhealthycompetition. Why so? Because people will with various attempts to win the competition, tricks and something that is considered not fair enough, will be pursued as well.

Third, the value of capitalis $m$ is contrary to the spirit of prosperity, capitalism is not towards what is commonly called social welfare, but capitalism is a way that will lead to prosperity only for the fittes (according to Darwin). People try to predict that after applying capitalism, they will see the "Invisible Hand", so that the welfare will come after. However, it is just nonsense[11].

On that basis, then it is deemed necessary to do social policytowards the creation of welfare. This policy certainly requires an "elan" or a spirit different from the spirit of capitalism, and that "elan" is social justice. It is in this context that some ideas in the concept of socialism become relegated. Although some other aspects of socialism get substantially less than the capitalist system, socialis $\mathrm{m}$ still offers something that does not exist in capitalism. Socialis $\mathrm{m}$ is considered extreme when it removes private ownership and takes over all ownership of the state, but economic equity and governmental responsibility with the socialist system are more prominent. In some cases, capitalism feels the need to adopt from the socialist system[11].

In Indonesia, at the time Indonesia was established, the founding fathers confirmed the promise with the people to realize the ideals of the nation that is social we lfare for all the people of Indonesia. The ideals were formulated in the preamble of the 1945 Constitution. The government's obligation is to protect the entire nation and the entire blood of Indonesia, to promote the common prosperity and to improve the life of the nation. Furthermore, in the body of the preamble contains the rights of citizens to get a job and a decent living for humanity, and guarantee the right to get an education. Similarly Article 33 gives the government the power to manage the most important natural resources for the greatest prosperity of the people and provide social security for the poor and neglected children [8].

As a country with open economy system, Indonesia cannot be separated from the influence of developments that occur in the international world. In the 1980s, oil prices plunged, causing many developing countries, especially oil exporting countries including Indonesia to be overwhelmed. This crisis made policy makers review development strategies and undertook a range of measures known as structural adjustment and economic stability. On the other hand, the foreign debt crisis was also being twisted due to lack of ability to pay the debt. The role of the state was diminishing as it lost the source of state revenues and was limited to efforts to maintain the pricing mechanism. The government then initiated a policy beginning with the scheduling of major projects, the devaluation and deregulation of banks in 1983 and subsequently emerging policy packages in monetary (and finance), fiscal, trade (and shipping) and investment, other obstacles were the widespread of corruption and manipulation of institutions bureaucracy [8].

\section{CONCLUSION}

1. The causes of mining sectorcannot be controlled by the Indonesian government is because Indonesia has not been able to utilize its natural resources, the state's not yet optimal in managing the mining sector. The un optimal governmental in managing mining in Indonesia has an impact on the contribution to the income and welfare of the people. Besides, also the regulation that has not been able to provide independent self-policing direction, this possibility is caused by the government cannot afford independently to mine the mining because the capital is not enough.

2. The concept of the State through mining can provide prosperity for the people of Indonesia.Article 33 Paragraph 3 clearly states that the state must control the various natural resources that exist and the people have full rights to the property. Welfare is in accordance with the concept of the welfare state, because the concept of the welfare state is the role of the state participates not only in the economic field but has transcended all aspects of people's lives. This is a form of state responsibility to his people as responsible in the life of the state.

\section{REFERENCES}

[1] P. A. Harahap, "Landasan Yuridis sistim Enkonomi Pancasila," in Sistim ekonomi Dan Demokrasi Ekonomi, 1st ed., S.-E. Swasono, Ed. Universitas Indonesia (UI-Pers), 1985.

[2] "Hukum Sumber Daya Alam Disektor Pertambangan," 2015. [Online]. Available: https://masrudimuchtar.wordpress.com/2015/10/19/hukum-sumberdaya-alam-disektor-pertambangan/. [Accessed: 05-Jul-2018].

[3] S. Gautama, Pengertian, Tentang Negara Hukum. Bandung: Alumni, 1983.

[4] S. Wignyosoebroto, Hukum Kolonial ke Hukum Nasional Dinamika Sosial Politik dalam Pembangunan Hukum Nasional, 1st ed. PT. RadjaGrapindoPersada, 1994.

[5] D. Kairys, Ed., The Politics Of Law A Progressive Critique. New York, 1989.

[6] J. Assihiddiqie, Gagasan Kedaulatan Rakyat Dalam Konstitusi dan Pelaksanaannya di Indonesia. Jakarta: PT. Ichtiar Baru Van Hove, 1994.

[7] D. I. Atmadja, Hukum Dagang Indonesia, Sejarah, Pengertian dan Prinsip-Prinsip Hukum Dagang. Malang: Setara Prees, 2011.

[8] "No Title." [Online]. Available: http://www.nasyiah.or.id/index.php=com-conten\&view=article.

[9] R. Quinny, "The Propetic Meaning Of Modern Walfare State," in Hukum Penanaman Modal, Jakarta: Raja Grafindo Persada, 2007.

[10] Y. B. Ardhiwisastra, Imunitas Kedaulatan Negara Di Fonum Pengadilan Asing. Bandung: Alumni, 1999.

[11] A. Triyatna, Hukum Ekonomi Islam Dari Politik Hukum Ekonomi Islam Sampai Pranata Ekonomi Syariah. Jakarta: UII Prees, 2012. 